\title{
Research on mariner growth prevention and anticorrosion tests of new type high toughness Resin/Steel/Copper alloy system
}

\author{
Jun Suo ${ }^{1, \text { a }}$ and Bo Zhang ${ }^{2}$ \\ ${ }^{1}$ Naval Academy of Armament, Beijing 100161, China \\ ${ }^{2}$ Qingdao Research Institute for Marine Corrosion, Qingdao 266071, China
}

\begin{abstract}
Multicomponent piping structure is common in ocean engineering material system. The new type of high toughness resin, marine steel and copper alloy as the main materials of the system is selected. The materials tests have been carried on in aging resistance, adhesion, water absorption, alternating temperature, salt spray resistance, weathering, electrochemical, antifouling and mariner growth prevention. The performances of the materials are analyzed by the quantitative results. The analysis shows that the high toughness resin coated on copper alloy materials and hull steel materials has good adhesion, water absorption, seawater resistance, alternating temperature resistance and salt spray resistance performances. Weathering performance meets the usage requirements of marine engineering. The electrochemical performance of the hull steel, copper alloy and high toughness resin materials is stable in seawater. High toughness resin/steel/copper alloy system has good anticorrosion, antifouling performance. The multicomponent piping system can satisfy the application in marine shipping requirements.
\end{abstract}

Keywords: high toughness; resin; multicomponent piping system; marine steel; copper alloy; antifouling; mariner growth prevention.

\section{Introduction}

Multicomponent piping structures are common in ocean engineering material system, widely used in vessels, drilling platforms and underwater facilities. Suitable material system selection is one of the highlights of marine materials research for a long time, as multicomponent piping system faces the multiple threats in the ocean, such as chemical/electrochemical corrosion [1], mariner growth [2, 3], sediment and so on. Especially in the condition of strong combination, the materials of multicomponent piping system need to have high toughness performance to maintain the stability of the structure in the complex ocean environment [4, 5]. Summing up, the material system of multicomponent piping structure [6] needs to meet the following main properties:

(1) seawater corrosion resistance; (2) antifouling performance; (3) potential corrosion performance; (4) anti-aging performance; (5) low water absorption performance; (6) The proper strength and toughness.

In this paper, a certain kind of material system with proper toughness, mariner growth prevention

a Corresponding author : mrsuo@163.com 
and anti-corrosion performances to fit the needs of ship navigation and the characteristics of ship hull irregular twisting is designed. The research on basic physical/chemical properties and antifouling/corrosion performance lab/practical tests of high toughness resin is done. The material system can be applied to be the components of the marine piping structure.

\section{Material system selection}

According to being applied outside ship hull, 945 marine steel is selected as the substrate material in the material system. The multicomponent piping functional materials, adhesive sealing compound material are screened out according to the substrates.

The principles of material system selection are as follows:

(1) Good molding process. (2) Good ability of anti-fouling, mariner growth prevention. (3) The electrochemical corrosion reaction is avoided to occur with the substrate material; (4) Good basic mechanics performance.

In this paper, the multicomponent piping alloy and adhesive sealing materials are selected and optimized based on the principles above.

\subsection{Alternative materials}

According to the requirements, this paper has carried on the preliminary investigation on the materials to select a suitable system for next study.

Table 1. Alternative materials list

\begin{tabular}{|c|c|c|c|c|c|}
\hline $\begin{array}{l}\text { Adhesive } \\
\text { sealing } \\
\text { material }\end{array}$ & $\begin{array}{l}\text { Basic physical } \\
\text { and chemical } \\
\text { properties }\end{array}$ & $\begin{array}{l}\text { Process } \\
\text { performance }\end{array}$ & $\begin{array}{l}\text { Piping } \\
\text { system } \\
\text { materials }\end{array}$ & $\begin{array}{l}\text { Basic } \\
\text { physical and } \\
\text { chemical } \\
\text { properties } \\
\end{array}$ & $\begin{array}{l}\text { Process } \\
\text { performance }\end{array}$ \\
\hline $\begin{array}{l}\text { A } \\
\text { two-component } \\
\text { polyurethane } \\
\text { materials }\end{array}$ & $\begin{array}{l}\text { Shear strength } \geq \\
2.5 \mathrm{MPa}, \quad \text { tensile } \\
\text { strength } \text { (DIN } \\
53504) \geq 2.5 \\
\mathrm{MPa} \text {, hardness } \\
\text { (Shore A) } 55 \sim \\
60, \text { elongation at } \\
\text { break > 300\%, } \\
\text { water absorption } \leq \\
1 \%, \quad \text { good } \\
\text { mariner growth } \\
\text { prevention } \\
\text { performance }\end{array}$ & $\begin{array}{l}\text { Surface drying } \\
\text { time }(23 \circ \mathrm{C}, \\
50 \% \text { relative } \\
\text { humidity) } 30 \sim \\
60 \text { minutes } \\
\text { curing speed } 4 \\
\mathrm{~mm} / \sim 24 \\
\text { hours }\end{array}$ & 945 hull steel & $\begin{array}{l}\text { Poor mariner } \\
\text { growth } \\
\text { prevention } \\
\text { performance }\end{array}$ & $\begin{array}{l}\text { Homogenous } \\
\text { with the } \\
\text { substrates. } \\
\text { Easy to weld. } \\
\text { Bending } \\
\text { forming is } \\
\text { difficult. }\end{array}$ \\
\hline $\begin{array}{l}\text { A } \\
\text { two-component } \\
\text { epoxy } \\
\text { materials }\end{array}$ & 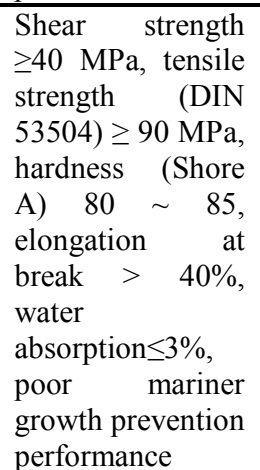 & $\begin{array}{l}\text { Surface dry } \\
\text { time }(23 \circ \mathrm{C}, \\
50 \% \text { relative } \\
\text { humidity) } 30 \sim \\
60 \text { minutes, } \\
\text { curing speed } 4 \\
\text { mm / } \sim 24 \\
\text { hours }\end{array}$ & $\begin{array}{l}\text { Copper alloy } \\
\text { pipe }\end{array}$ & $\begin{array}{l}\text { Good mariner } \\
\text { growth } \\
\text { prevention } \\
\text { performance }\end{array}$ & $\begin{array}{l}\text { Different from } \\
\text { the substrates. } \\
\text { Potential } \\
\text { corrosion } \\
\text { exists. } \\
\text { Bending } \\
\text { forming is } \\
\text { easy. }\end{array}$ \\
\hline
\end{tabular}


Based on the properties illuminated in Table 1, the selected materials are as follows:

(1) In terms of resin adhesive sealing material, the two-component polyurethane has good performances of mariner growth prevention, elongation at break and toughness. The process performance is just about as epoxy's. Therefore, the two-component polyurethane is selected as the adhesive material in the subsequent experiments.

(2) In terms of piping materials, 945 steel is lack of good mariner growth prevention performance, although it can be welded with the substrates without potential corrosion. Therefore, copper alloy pipes, which can be insulated from the substrates by adhesive resin, are used in the subsequent tests.

\section{Experimental procedure}

The specimens are prepared according to GB/T14522, GB 9274-1988, GB/T 5210-2006, GB/T 1462-2005, GJB 150.5-1986, GB/T 1771-2007, GB/T 14522-2008, JB/T 7901-1999, JB/T 8424-1996 to meet the requirement of aging performance test, water resistance test, adhesion test, water absorption test, temperature alternating test, salt spray and weathering resistance test, electrochemical test and natural seawater test.

The high toughness resin coating is brushed inside the 945 steel tank. Then the copper alloy pipe is fixed promptly. After 24-hour curing, the high toughness resin is continually poured into the steel tank with fixed distance between the pipe and the bottom of the tank. The components for the real sea tests are ready after another 24-hour curing.

\section{Material performance test}

\subsection{Aging performance}

In accordance with GB/T14522-2008[7], the resin specimens are prepared to determinate the change of hardness, tensile strength and elongation at break, as shown in Table 2.

Table 2. The influence of accelerated aging time on the properties

\begin{tabular}{ccccc}
\hline $\begin{array}{l}\text { Serial } \\
\text { number }\end{array}$ & Aging time, day & Tensile strength , MPa & Elongation at break, \% & Hardness, Shore A \\
\hline $\mathbf{1}$ & 0 & 4.28 & 370 & $\mathbf{5 9 . 6}$ \\
$\mathbf{2}$ & 5 & 4.82 & 298 & $\mathbf{6 1}$ \\
$\mathbf{3}$ & 10 & 4.52 & 216 & $\mathbf{6 5 . 6}$ \\
$\mathbf{4}$ & 15 & 5.24 & 297 & $\mathbf{6 4 . 6}$ \\
$\mathbf{5}$ & 20 & 5.18 & 271 & 65.4 \\
\hline
\end{tabular}

\subsection{Seawater resistance}

In accordance with GB/T14522-2008, the resin specimens are prepared to determinate the change of hardness, tensile strength and elongation at break in natural seawater, as shown in Table 3.

Table 3. The influence of immersed time in seawater on the properties

\begin{tabular}{cccccc}
\hline $\begin{array}{l}\text { Serial } \\
\text { number }\end{array}$ & $\begin{array}{l}\text { Time in seawater, } \\
\text { month }\end{array}$ & $\begin{array}{l}\text { Water } \\
\text { absorption, \% }\end{array}$ & $\begin{array}{l}\text { Tensile strength, } \\
\text { MPa }\end{array}$ & $\begin{array}{l}\text { Elongation at } \\
\text { break, \% }\end{array}$ & $\begin{array}{l}\text { Hardness, } \\
\text { Shore A }\end{array}$ \\
\hline 1 & 0 & 0 & 4.45 & 413 & 61 \\
2 & 1 & 0.27 & 3.58 & 243 & 63 \\
3 & 3 & 0.12 & 4.40 & 210 & 66 \\
4 & 6 & 0.07 & 4.80 & 236 & 65 \\
5 & 9 & 0.11 & 7.14 & 265 & 65 \\
6 & 12 & 0.21 & 4.68 & 279 & 62 \\
\hline
\end{tabular}


In accordance with GB 9274-1988 [8],hull steel material specimens coated with high toughness resin are immersed in Qingdao seawater of $40{ }^{\circ} \mathrm{C}$ for $1000 \mathrm{~h}$, observed whether phenomena of color change, bubble, crack, warped surface or break off occur on specimens' surfaces. The morphology of the specimens before and after the test is shown in Figure 1.
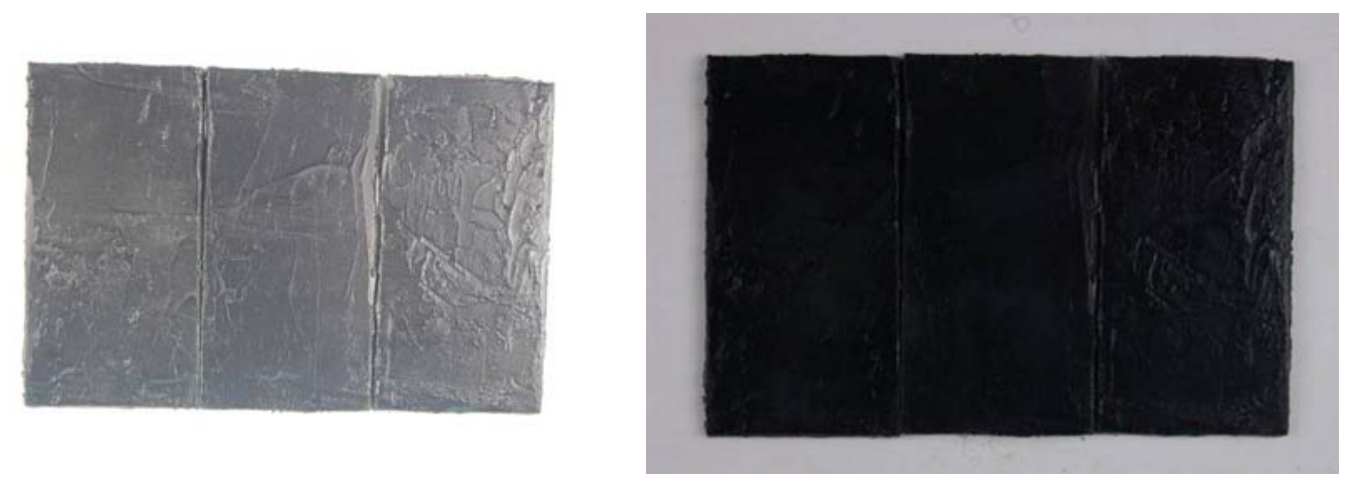

Figure 1. The morphology of the high toughness resin specimens before and after the seawater test

\subsection{Adhesion test}

The piping alloy and hull steel material specimens coated with high toughness resin are immersed in Qingdao seawater at room temperature for 10,20 and 30 days. In accordance with GB/T 5210-2006[9], the results of adhesion test are shown in Table 4.

Table 4. The results of the specimen adhesion tests after the seawater test for 10, 20 and 30 days

\begin{tabular}{ccccc}
\hline Serial number & Specimen & \multicolumn{3}{c}{ Adhesion force, MPa } \\
\hline & & 10 days & 20 days & 30 days \\
\cline { 3 - 5 } $\mathbf{1}$ & Copper alloy specimen & 1.95 & 1.98 & 1.94 \\
$\mathbf{2}$ & Hull steel specimen & 2.06 & 2.03 & 1.99 \\
\hline
\end{tabular}

\subsection{Water absorption test}

In accordance with GB/T 1462-2005[10], hull steel specimens coated with high toughness resin are investigated by water absorption test. The specimens are put in $50^{\circ} \mathrm{C}$ oven for $24 \mathrm{~h}$, cooled to room temperature and weighed; then put in $23{ }^{\circ} \mathrm{C}$ distilled water for $24 \mathrm{~h}$, weighed after removing surface moisture. The results are shown in Table 5.

Table 5. Water absorption test results

\begin{tabular}{ccccc}
\hline Serial number & weight before test, $\mathbf{g}$ & weight after test, $\mathbf{g}$ & $\begin{array}{l}\text { Water absorption } \\
\text { capacity, } \mathbf{g}\end{array}$ & Average, $\mathbf{g}$ \\
\hline $\mathbf{1}$ & 119.743 & 119.786 & 0.043 & \\
$\mathbf{2}$ & 121.262 & 121.307 & 0.045 & 0.045 \\
$\mathbf{3}$ & 118.908 & 118.956 & 0.048 & \\
\hline
\end{tabular}

\subsection{Temperature alternating test}

In accordance with GJB 150.5-1986[11], the piping alloy and hull steel material specimens coated with high toughness resin are tested in alternating temperature chamber under the conditions of $40{ }^{\circ} \mathrm{C} \sim 70{ }^{\circ} \mathrm{C}$ temperature alternating, $2 \mathrm{~h}$ per cycle, 50 cycles. 

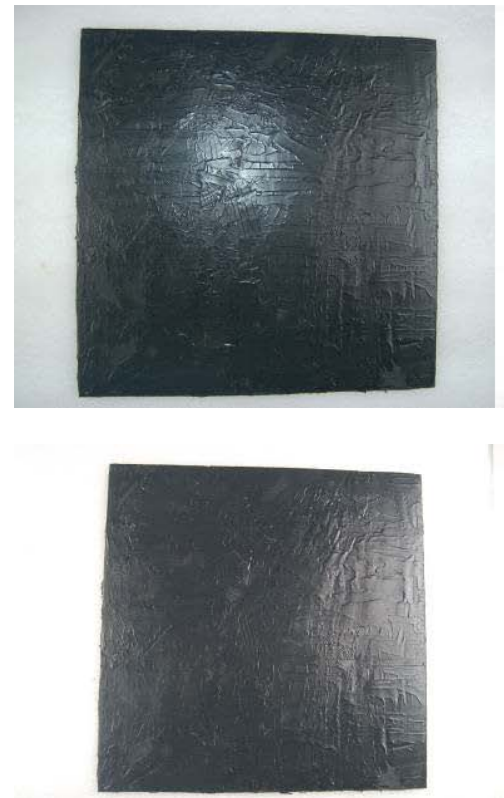

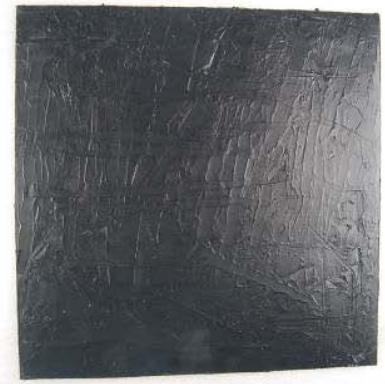

A. Before the test

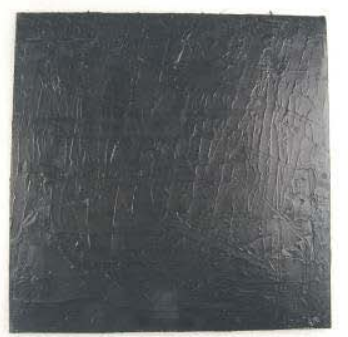

B. After the test
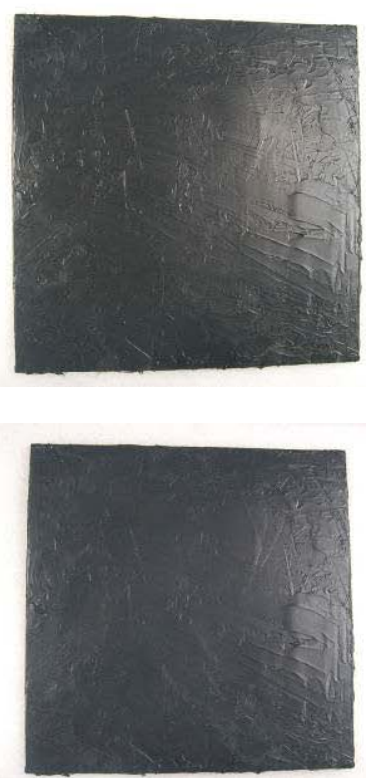

Figure 2. The morphology of the specimens before and after the temperature alternating test with copper alloy as the substrates

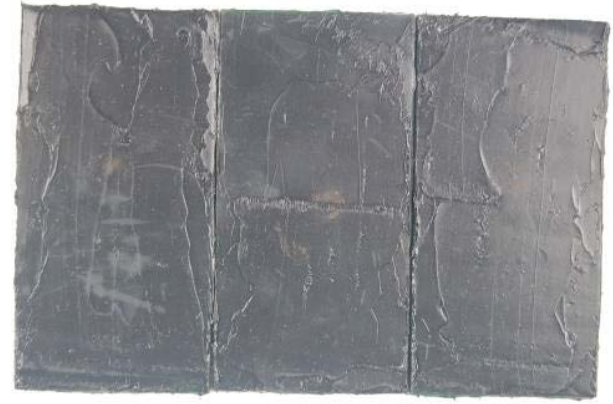

A. Before the test

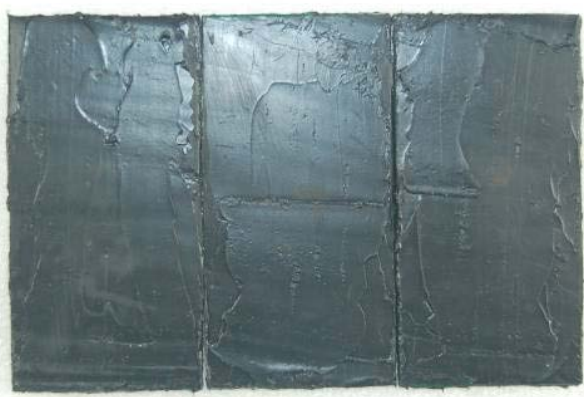

B. After the test

Figure 3. The morphology of the specimens before and after the temperature alternating test with hull steel as the substrates

\subsection{Salt spray resistance}

In accordance with GB/T 1771-2007[12], hull steel material specimens coated with high toughness resin are tested in salt spray chamber under the condition of $35^{\circ} \mathrm{C}$, the test medium concentration of $50 \mathrm{~g} / \mathrm{L}$ (prepared with distilled water and sodium chloride), spraying for $15 \mathrm{~min}$ and pause for $45 \mathrm{~min}$, $1000 \mathrm{~h}$, observed whether phenomena of color change, bubble, crack, warped surface or break off occur on specimens' surfaces. 

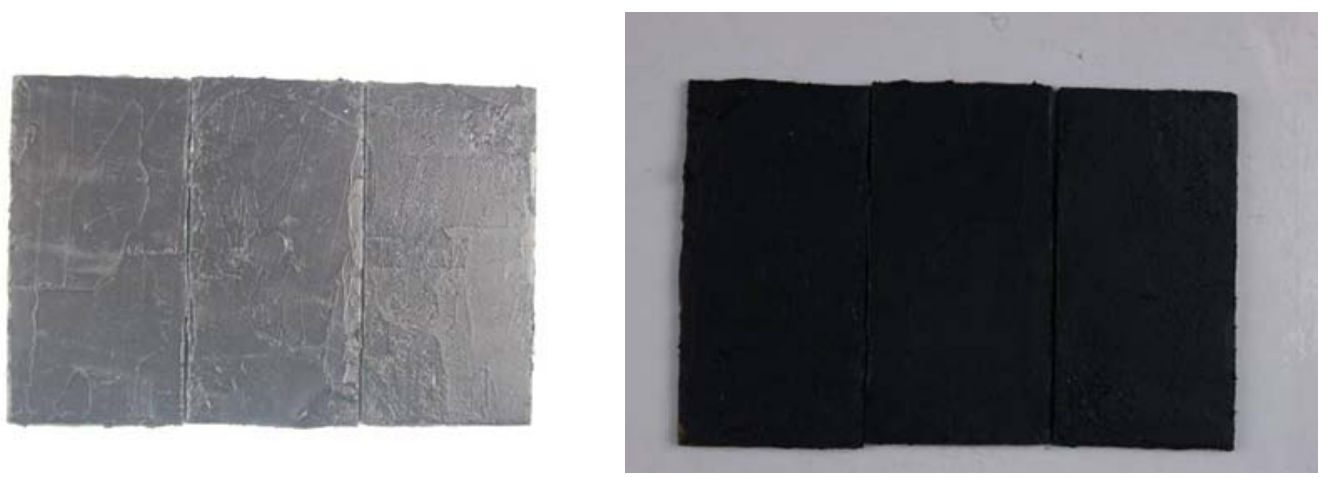

Figure 4. The morphology of the high toughness resin specimens before and after the salt spray test

\subsection{Weathering resistance}

In accordance with GB/T 14522-2008and GB/T 528-2009[13], the specimens are tested in ultraviolet aging chamber (Test time $20 \mathrm{~d}, 5 \mathrm{~d}$ as a test cycle. The light phase at $60{ }^{\circ} \mathrm{C}$ for $8 \mathrm{~h}$, the condensing stage at $50{ }^{\circ} \mathrm{C}$ for $4 \mathrm{~h}$ per cycle). The hardness and tensile strength are tested at the end of each cycle and the test data are shown in Table 6.

Table 6. High toughness resin weathering test data

\begin{tabular}{cccc}
\hline Serial number & Test time, day & Hardness, shore hardness & tensile strength, MPa \\
\hline $\mathbf{1}$ & 0 & 60 & 465 \\
$\mathbf{2}$ & 5 & 61 & 312 \\
$\mathbf{3}$ & 10 & 66 & 260 \\
$\mathbf{4}$ & 15 & 65 & 242 \\
$\mathbf{5}$ & 20 & 65 & 180 \\
\hline
\end{tabular}

\subsection{Electrochemical test}

In accordance with JB/T 7901-1999 [14], copper alloy piping material and hull steel specimens coated with high toughness resin are immersed in Qingdao seawater. The potentials among piping materials/resin, hull steel/resin are measured every day. The reference electrodes are saturated calomel electrode. Test results are shown in Figure 5.

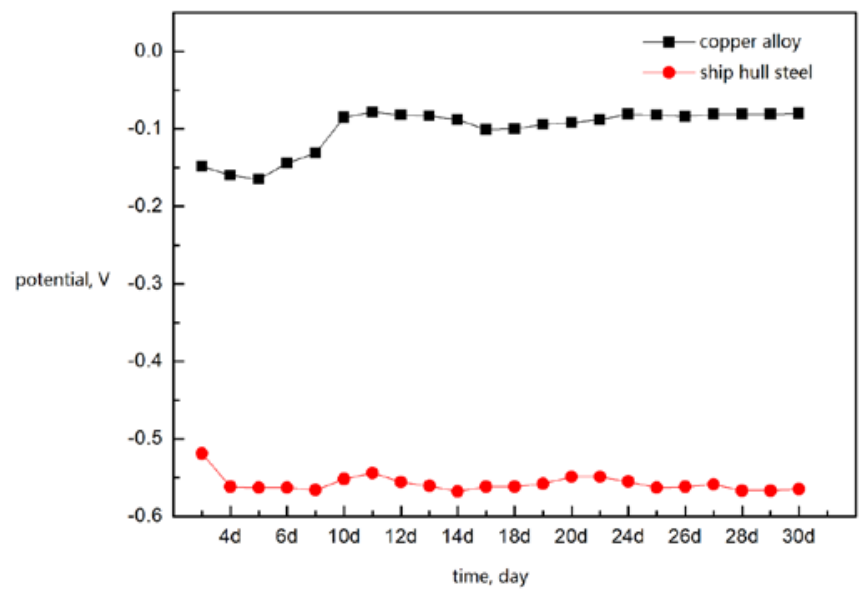

Figure 5. The electrochemical test data of copper alloy piping material and hull steel specimens coated with high toughness resin 


\subsection{Test in natural seawater}

In accordance with JB/T 8424-1996[15], copper alloy piping material and hull steel specimens coated with high toughness resin are respectively hang in full immersion zone, tidal range zone and splash zone for test. The test period is 12 months. The morphology of the copper alloy piping material and hull steel specimens coated with high toughness resin 12 months later is shown in Figure 6.

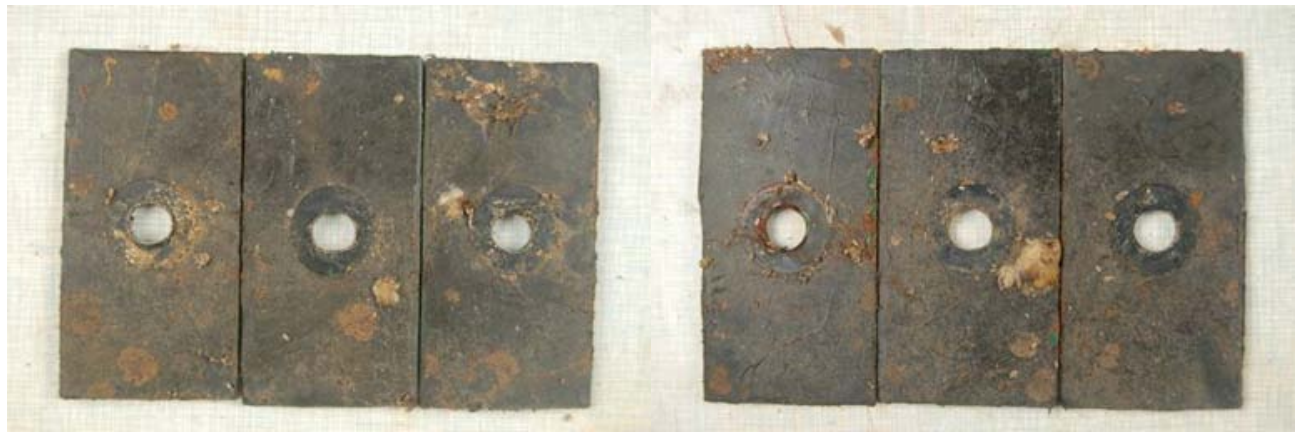

Copper alloy pipe material as substrates Hull steel material as substrates A. In full immersion zone

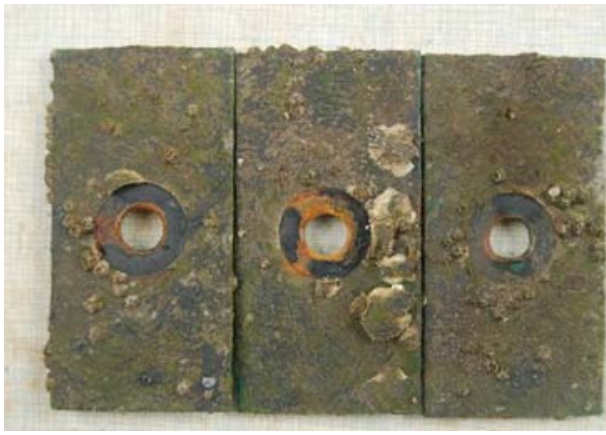

Copper alloy pipe material as substrates

B. In tidal range zone

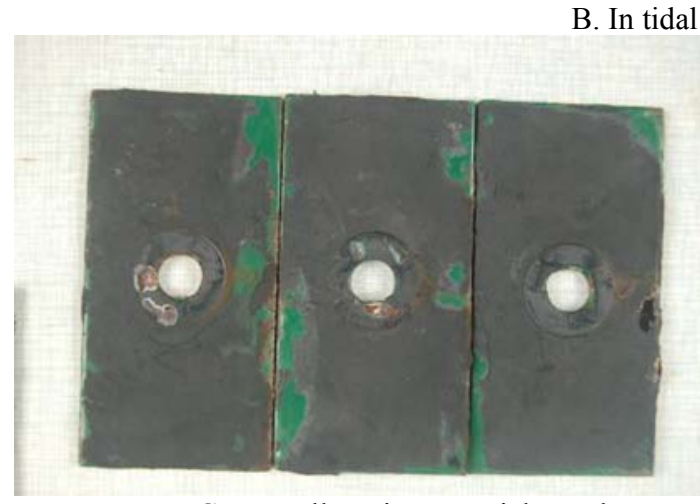

Copper alloy pipe material as substrates

C. In splash zone

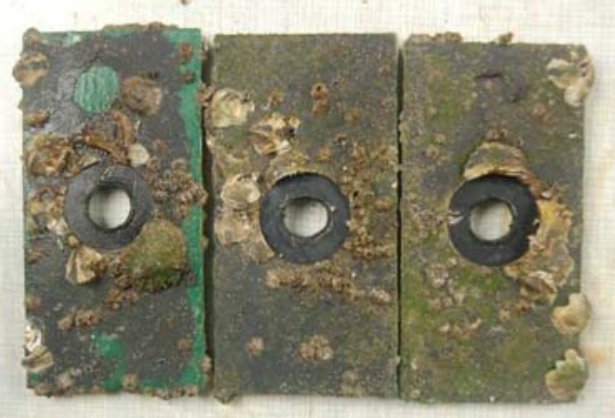

Hull steel material as substrates

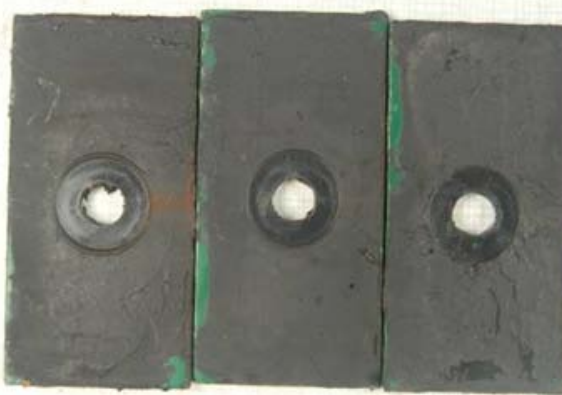

Hull steel material as substrates

Figure 6. The morphology of the specimens tested in natural seawater after 12 months

\subsection{Mariner growth prevention test in natural seawater}

The components made of 945 hull steel, copper alloy pipe and high toughness resin are placed in full immersion zones of Qingdao, Zhoushan and Sanya seawater for 12 months.

The morphology of the components after the test is shown in Figure 7, 8 and 9. 


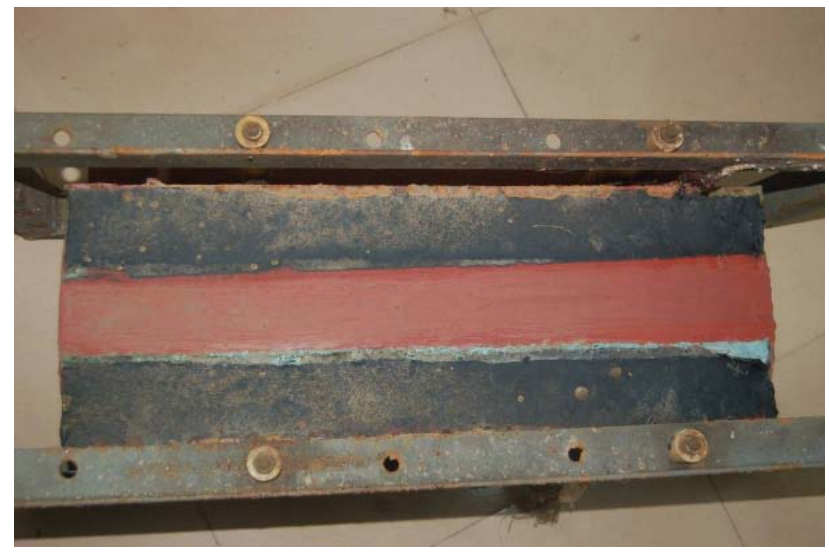

Figure 7. The morphology of the component in Qingdao seawater after 12 months

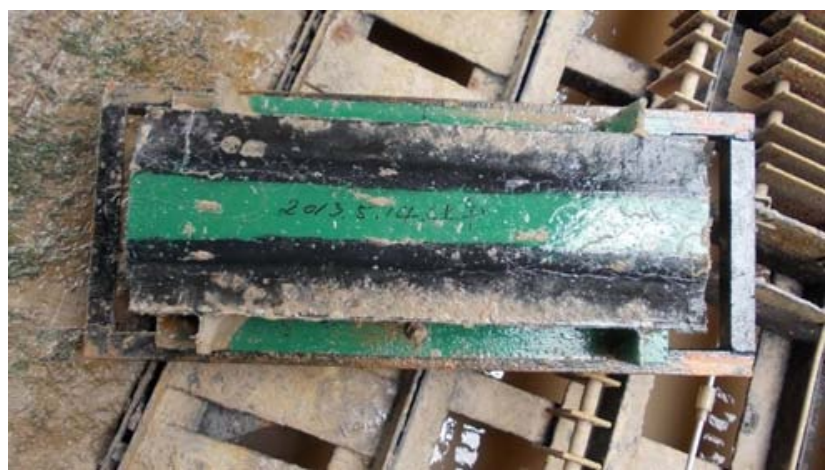

Figure 8. The morphology of the component in Zhoushan seawater after 12 months

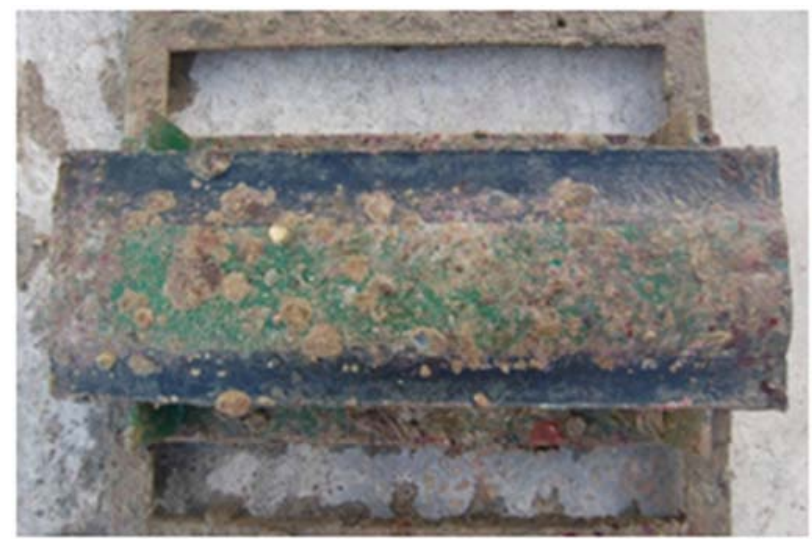

Figure 9. The morphology of the component in Sanya seawater after 12 months

\section{Material performance analysis}

In the resin aging performance test study, Table 2 shows the aging performance remains stable with aging time. At the start of the aging, the hardness and tensile strength increased, elongation decreased. The performances tend to constant values, satisfying the requirement.

The phenomena of color change, bubble, crack, warped surface or break off doesn't occur on the specimens' surfaces after the seawater absorption tests. In Table 3, the seawater absorption rates show 
little changes (less than $0.5 \%$ ) while the specimens are dipped in the seawater, although the test performance data exist some random fluctuations. The tensile strength, elongation at break and hardness fluctuate within permit ranges. The basic performances of the specimens maintain stable after one year's seawater immersion, satisfying the requirements.

Copper alloy and hull steel specimens coated with high toughness have steady adhesion performance in the test cycle shown in Table 4.The failure type is cohesion failure of high toughness resin.

The water absorption test shows that the high toughness resin has an extremely low absorption rate, satisfying the requirement of stable performance in seawater.

In alternating temperature test, the high toughness resin coated on the copper alloy and hull steel doesn't show obvious changes on the surface, as shown in Figure 2, 3.

After the salt spray test, the specimens' surfaces doesn't show obvious change, such as color change, bubble, crack, warped surface or break off, as shown in Figure 4.

The data in table 6 show that the hardness of high toughness resin specimens increases, while the tensile strength decreases along with the increase of the test time in weathering tests. This shows that the resin material in weathering test has certain aging problem. But during a minor repair cycle, the resin's performance remains stable under the waterline to avoid direct sunlight, satisfying the requirements of weathering.

The data in Figure 5 show that the potentials of the copper alloy and hull steel coated with high toughness resin in seawater are basically stable in electrochemical tests after 30 days. The potential of the copper alloy specimen coated with high toughness resin is about $-0.08 \mathrm{~V}$, while the one of the hull steel specimen coated with high toughness resin is about $-0.56 \mathrm{~V}$. The test results show that the high toughness resin has good insulation performance, which can prevent the hull steel and copper alloy pipe in seawater from electrochemical corrosion.

The morphology of figure 6 shows that a small amount of sea creatures grow on the components in Qingdao seawater after 12 months. There are nearly no sea creatures but only a small amount of sediment on the components in Zhoushan seawater after 12 months. A large amount of sea creatures grow on the anticorrosive coating part of the components but relatively less creatures grow on the surface of the resin in Sanya seawater after 12 months.

\section{Conclusion}

Multicomponent piping structure material system is designed according to the consideration of chemical/electrochemical corrosion, sediment/sea creature's growth and the characteristics of its structural rigidity and toughness.

Through the tests, it can be seen that the high toughness resin coated on copper alloy materials and hull steel materials has good adhesion, water absorption, seawater resistance, alternating temperature resistance and salt spray resistance performances. Weathering performance meets the usage requirements of marine engineering. The electrochemical performance of the hull steel, copper alloy and high toughness resin materials is stable in seawater. High toughness resin/steel/copper alloy system has good anticorrosion, antifouling performance. The multicomponent piping system can satisfy the application in marine shipping requirements.

Compared with the previous systems, the material system in this paper can well satisfy the requirements of the piping structure outside ship hull, and has a good application prospect.

\section{References}

1. Scott M. Environmentally Friendly Anticorrosion Coating for High Strength Fasteners [R]. ADA551772, 1 (2011)

2. Susanne M. Quantifying Trophic and Demographic Rates of Plankton-Rich Layers in East Sound, Orcas Island, Washington [R]. ADA574185, 9 (2007)

3. Chi Z, Fang Y. Exopolysaccharides from Marine Bacteria [J]. Journal of Ocean University of 
China, 4(1): 67-74 (2005)

4. Klinov I Y, Udyma P G. Use of Polymers in Anticorrosion Technology [R]. AD0602584, 4 (1964)

5. Zhang J, Jiang S, Liang Y. Development of Marine FRP Duct [J]. Development and Application of Materials, 6: 40-42. (1997) (in Chinese)

6. Oaks D, Stanford M, Wilson B. The Value and Impacts of Alternative Fuel Distribution Concepts, Assessing the Army's Future Needs for Temporary Fuel Pipelines [R]. ADA497735, 1 (2009)

7. GB/T 14522-2008. Artificial Weathering Test Method for Plastics, Coating and Rubber Materials Used for Machinery Industrial Product-Fluorescent UV Lamps [S]. (in Chinese)

8. GB 9274-1988. Paints and Varnishes - Determination of Resistance to Liquids [S]. (in Chinese)

9. GB/T 5210-2006. Paints and Varnishes_-Pull-off Test for Adhesion [S]. (in Chinese)

10. GB/T 1462-2005. Test Methods for Water Absorption of Fiber Reinforced Plastics [S]. (in Chinese)

11. GJB 150.5-1986. Environmental Test Methods for Military Equipments Temperature Shock Test [S]. (in Chinese)

12. GB/T 1771-2007. Determination of Resistance to Neutral Salt Spray (fog) [S]. (in Chinese)

13. GB/T 528-2009. Rubber, Vulcanized or Thermoplastic - Determination of Tensile Stress-Strain Properties [S]. (in Chinese)

14. JB/T 7901-1999. Metals Materials-Uniform Corrosion-Methods of Laboratory Immersion Testing [S]. (in Chinese)

15. JB/T 8424-1996. Metal Covering Layer and Organic Coating-Methods of Natural Seawater Corrosion Testing [S]. (in Chinese) 